Res Pública Revista de Historia de las Ideas Políticas

ISSN: $1131-558 \mathrm{X}$

https://dx.doi.org/10.5209/rpub.70797

\title{
El pensamiento de José Carlos Mariátegui: ¿entre marxismo y populismo?
}

\author{
David Cardozo Santiago*
}

Recibido: 24 de julio de 2020 / Aceptado: 31 de agosto de 2020

Resumen. El presente artículo pretende indagar acerca del lugar central que José Carlos Mariátegui concediera a las supervivientes estructuras comunitarias del ayllu en la construcción de un socialismo adaptado a las condiciones del Perú. Esta indagación nos permitirá contrastar las soluciones al problema de la tierra y al problema del indio, tal y como fueron concebidas por el pensador peruano, con los planteamientos realizados por los populistas rusos en relación con la pervivencia de la comuna rural (la obshina). Finalmente, estaremos en condiciones de cuestionarnos en qué medida los caminos recorridos por políticos de la talla de Herzen y Chernyshevski, en la Rusia del siglo XIX, y por Mariátegui, en el Perú de las primeras décadas del XX, se apartan del marxismo del propio Marx.

Palabras clave: Mariátegui; Populismo; Marxismo latinoamericano; Comunidad.

\section{[en] The Thought of José Carlos Mariátegui: Between Marxism and Populism?}

\begin{abstract}
This paper focuses on the central place that José Carlos Mariátegui granted to the surviving ayllu community structures in the construction of a socialism adapted to the conditions of Peru. This inquiry will allow us to contrast the solutions to the problem of the land and the problem of the Indian, as they were conceived by the Peruvian thinker, with the approaches made by the Russian populists regarding the survival of the rural commune (the obshina). Finally, we will be in a position to question to what extent the paths traveled by politicians of the intellectual stature of Herzen and Chernyshevski, in the Russia of the 19th century, and by Mariátegui, in the Peru of the first decades of the 20th century, depart from the Marxism of the Marx himself.
\end{abstract}

Keywords: Mariátegui; Populism; Latin American Marxism; Community.

Sumario. 1. "Una versión especial de populismo adaptada al Perú". 2. La comunidad: origen y destino. 3. Marxismo más allá del obrerismo. 4. Consideraciones finales. Mariátegui: marxista-populista. 5. Bibliografía.

Cómo citar: Cardozo Santiago, D. (2021). El pensamiento de José Carlos Mariátegui: ¿entre marxismo y populismo?. Res Pública. Revista de Historia de las Ideas Políticas, 24(1), 75-84.

No vale la idea perfecta, absoluta, abstracta, indiferente a los hechos, a la realidad cambiante y móvil; vale la idea germinal, concreta, dialéctica, operante, rica en potencia y capaz de movimiento

José Carlos Mariátegui, Editorial de Amauta, No 17, año II, Lima, septiembre de 1928

Tras la muerte de José Carlos Mariátegui -el 16 de abril de 1930-, no sólo el Perú sino toda América Latina perdía a uno de los faros intelectuales que con mayor vigor y compromiso había guiado a las masas en la ardua lucha por emanciparse del oneroso resabio que el régimen colonial hispano había legado a las repúblicas independientes y cuyos efectos no habían remitido en pleno siglo XX. Los cortejos fúnebres y las notas de pésame rápidamente fueron cediendo paso a artículos laudatorios que, tras la profusión de elogios, escondían una voluntad de captura y monopolización hermenéutica de una obra tan rica como la del Amauta. Entre las innume- rables polémicas en torno a la recta interpretación del pensamiento mariateguiano, nos proponemos analizar una de ellas, cuya relevancia permanece aún vigente: ¿fue Mariátegui un marxista ortodoxo y obediente de las directrices del Komintern?, ¿o fue un populista, semejante a los naródniki rusos, tal y como defendiera Miroshevski? La respuesta a este dilema trasciende al ámbito de las discusiones eruditas y se impone como una de las cuestiones estratégicas más acuciantes en el seno del marxismo latinoamericano.

El presente artículo pretende indagar, desde una "lectura laica" - por utilizar la atinada expresión de Ro-

Universidad Complutense de Madrid/Universidade Federal de Bahia dcardozosantiago@ucm.es 
bert Paris-, el lugar central que el pensador moqueguano concediera a las supervivientes estructuras comunitarias del ayllu, estructuras que supieron integrarse y resistir tanto al proceso colonial como a las repetidas embestidas republicanas. Esta exposición de la dimensión propositiva de la obra del autor de los Siete ensayos de interpretación de la realidad peruana, nos permitirá contrastar sus soluciones al problema de la tierra y del indio en el Perú con la de una tradición marxista que no se agota en la estrategia obrerista, sino que se piensa a sí misma como una teoría abierta a revisiones y adaptaciones que le permiten ser una herramienta fértil, capaz de aprehender las distintas realidades específicas de los países periféricos. Finalmente, intentaremos brindar algunas perspectivas elementales acerca de los planteamientos de los populistas rusos en relación con la pervivencia de la comuna rural (la obshina), a fin de cuestionarnos en qué medida las soluciones halladas por políticos de la talla intelectual de Herzen y Chernyshevski, en la Rusia del siglo XIX, y por Mariátegui, en el Perú de las primeras décadas del $\mathrm{XX}$, se apartan del marxismo del propio MarX.

\section{1. "Una versión especial de populismo adaptada al Perú"}

El artículo de Miroshevski El “populismo” en el Perú. Papel de Mariátegui en la historia del pensamiento social latinoamericano, publicado en 1941, constituye el documento que con mayor nitidez revela la interpretación oficial del Komintern sobre el pensamiento de Mariátegui una década después de su muerte. La representatividad del testimonio de Miroshevski no se debe exclusivamente a su reputación como historiador dedicado al estudio de las realidades latinoamericanas, sino fundamentalmente - como bien destaca Aricó- al hecho de ser uno de los asesores claves para el Buró Latinoamericano del Komintern ${ }^{1}$.

En los primeros enunciados del referido artículo ya se deja entrever, sin ambages ni eufemismos, el veredicto soviético: "Algunos rasgos sustanciales del populismo ruso se han manifestado en diversos movimientos revolucionarios pequeñoburgueses de una serie de países atrasados, particularmente de Latinoamérica. [...] Estas ideas encontraron su expresión más adecuada en los trabajos teóricos de José Carlos Mariátegui"'. Unas páginas más adelante, Miroshevski destaca a Mariátegui como uno de los integrantes del ala progresista de la intelectualidad vinculada al aprismo, pero sin disimular la poca estima que siente por las posiciones defendidas por el pensador peruano, acaba calificándolo como "joven literato que aspiraba «acercarse al pueblo»"3. A partir de estas afirmaciones iniciales del historiador ruso, no es difícil inferir que no apreciaba en la figura de Mariátegui

J. Aricó, “Introducción”, en Aricó, J. (ed.), Mariátegui y los orígenes del marxismo latinoamericano, México, Pasado y Presente, 1980, p. 40.

2 V.M. Miroshevski, "El «populismo» en el Perú. Papel de Mariátegui en la historia del pensamiento social latinoamericano", en Aricó, J. (ed.), Mariátegui y los orígenes del marxismo latinoamericano, México, Pasado y Presente, 1980, p. 55.

3 Ibidem, p. 58. a un pensador descollante dentro de la naciente intelliguentsia peruana, sino un émulo -aun sin haber recibido influencia directa alguna- de los naródniki rusos. El afán por "acercarse al pueblo" de Mariátegui, diagnosticado por Miroshevski, coincide plenamente con el lema de los populistas rusos que entendieron su labor revolucionaria como una continua ida hacia el pueblo.

Otro de los aspectos en los que la crítica de Miroshevski puede ser interpretada como metonímica en relación con la catarata de matizaciones y rectificaciones que algunos pretendidos marxistas ortodoxos realizaran al pensamiento de Mariátegui, es el de la presencia de impurezas doctrinales en el marxismo del pensador peruano. Así, por ejemplo, se manifiesta Miroshevski en relación con este aspecto: "Había mucha confusión en sus puntos de vista. Se consideraba «marxista», pero al mismo tiempo tenía a Georges Sorel, teórico del anarcosindicalismo, como su maestro". La extendida presencia de este tópico, parece haber sido un canon general entre los marxistas oficiales. Sólo hay que cotejar otro artículo publicado un año antes que el de Miroshevski [1940], cuyo autor, Jorge Núñez Valdivia, defiende lo siguiente: "Mariátegui representa en la historia cultural peruana el pasaje del idealismo al materialismo. Empero, nuestro escritor no actuó con desenvoltura teórica dentro de la órbita del materialismo consecuente, vale decir, del materialismo dialéctico. La experiencia idealista no fue definitivamente superada"5. La ausencia de materialismo dialéctico se presenta como el arma arrojadiza lanzada por aquellos probos marxistas que han conseguido escapar de la platónica caverna en la que los intelectuales y las masas cohabitan; este destino compartido por todos los marxistas heterodoxos es, sin embargo, síntoma inequívoco de la fertilidad de su pensamiento en el suelo de la praxis ${ }^{6}$.

\section{Idem.}

J. Núñez Valdivia, "José Carlos Mariátegui y el materialismo dialéctico”, en Aricó, J. (ed.), Mariátegui y los orígenes del marxismo latinoamericano, México, Pasado y Presente, 1980, p. 293.

6 Los paralelismos entre la vida y obra de Mariátegui y Gramsci han sido suficientemente desarrollados en numerosos artículos y ensayos en los últimos años. A nuestro entender, deben ser resaltados, además de los aspectos comunes derivados en buena medida de la profunda huella que la experiencia italiana dejó en la formación intelectual y política del peruano, las críticas análogas que recibieron sus intentos por adaptar el marxismo a unas realidades nacionales en las que el modo de producción capitalista aún no había completado su subsunción real. Una de las críticas sobre el pensamiento del sardo que más repercusión han tenido en el seno del marxismo -fundamentalmente por la relevancia del emisor- ha sido la de Louis Althusser. Si nuestra interpretación es correcta, en las palabras del francés sobre Gramsci suenan las mismas notas que en las de la crítica de Núñez Valdivia sobre Mariátegui. Dejamos que sea el lector quien lo juzgue: "Habría que reconocer que en estas condiciones Gramsci no pudo dar, desprovisto de una correcta concepción de las ciencias y de la relación específica que la filosofía establece con las ciencias, una definición completa y correcta de la filosofía. Vio correctamente la relación fundamental de la filosofía con la política, pero no discernió la relación específica de la filosofía con las ciencias. [...] Si se tiene en consideración este equívoco, se comprenderá fácilmente que haya podido provocar la tendencia, sensible en Gramsci, a confundir la filosofía marxista (materialismo dialéctico) con la ciencia de la historia (cuya «teoría general» es el «materialismo histórico»). Esta confusión es consagrada en Gramsci 1) por la supresión del término clásico de Materialismo Dialéctico (al que reprocha sus resonancias positivistas, sin discernir el contenido efectivo que designa esta apelación, a saber, la relación de la filosofía con las ciencias), y 2) por la amal- 
Pero el núcleo de la crítica de Miroshevski no debe ser ubicado en la heterodoxia de las fuentes en las que se forja el marxismo de Mariátegui, sino en dos elementos concomitantes entre sí y que marcan el sendero estratégico trazado por el Amauta para los países andinos: el lugar del proletariado en la revolución y el potencial de las estructuras comunitarias en la construcción del socialismo futuro.

En relación con el primer punto, el del lugar del proletariado en la revolución socialista en las condiciones del Perú, la crítica de Miroshevski reza así:

En 1926-1928, Mariátegui propaga las ideas del "socialismo" pequeñoburgués, se convierte en un propagandista de la "revolución campesina socialista". La limitación pequeñoburguesa, aún no superada en sus ideas, le impedía comprender el papel histórico del proletariado. Mariátegui tenía la convicción de que el Perú marcharía hacia la revolución por su propio camino, por un camino "especial". Consideraba a los campesinos indígenas peruanos como "colectivistas naturales", creía que éstos realizarían la revolución socialista independientemente, sin la dirección del proletariado revolucionario ${ }^{7}$.

Y unas líneas más adelante, el propio Miroshevski atribuye a Mariátegui un viraje que, sin embargo, la muerte interrumpió, impidiendo así el encauzamiento al recto sendero etapista defendido por el Komintern en aquellos años:

Mariátegui dirigió la creación (en octubre de 1928) del partido "obrero y campesino" socialista y fue elegido su secretario general. En este tiempo todavía consideraba al proletariado como un simple "apéndice" de las masas campesinas indígenas. Pero ya había una brecha en las anteriores convicciones políticas de Mariátegui, brecha que se ensanchaba día a día ${ }^{8}$.

El segundo punto en el que se centra la crítica del historiador ruso es en la supuesta idealización efectuada por Mariátegui del pasado incaico y la resistencia y vitalidad de la comunidad campesina siglos después de la Conquista y las Independencias nacionales. El dictamen de Miroshevski sobre la historia Inca, si bien -y esto debe ser reconocido- sustentado por conocimientos historiográficos reseñables, fue sesgado y basado, en lo fundamental, en la perspectiva heredada de los cronistas españoles. Un análisis en profundidad del pasado del Tawantinsuyu nos llevaría demasiado lejos en la discusión, no obstante no puede pasarse por alto la ingenua inferencia efectuada por Miroshevski acerca de "la entrega de las dos terceras partes de la cosecha de las tierras comunales al Cápac-Inca" como testimonio de relaciones semiesclavistas, más aun si tenemos en cuenta que en los Andes precoloniales no existió el

gama de la ciencia de la historia y de la filosofía bajo la expresión única de «filosofía de la praxis». Creo que en este caso no se trata de una mera recomposición terminológica" (L. Althusser, "Carta a Dal Sasso", en Para leer El Capital, México D.F., Siglo XXI, 2004, pp. 15-16).

V.M. Miroshevski, op. cit., p. 58.

Ibidem, p. 59.

Ibidem, p. 63. comercio ni mucho menos el dinero y que, por tanto, la redistribución del excedente productivo se efectuaba por la vía de una red de reciprocidades que ligaban el poder estatal incaico con el de los distintos ayllus ${ }^{10}$. Al no tener en cuenta estas claves históricas del pasado andino, el historiador ruso se sirvió del intento de revalorización mariateguiana del pasado incaico, como mordaz argumento contra el moqueguano: "Toda la «explicación» del régimen social inca hecha por Mariátegui está basada en hechos alterados, en fantasías. Es realmente un agradable cuento de lo inexistente" 11 .

La supervivencia de la comunidad indígena a comienzos del siglo XX y, sobre todo, su potencial, tanto a nivel estructural como en relación con la costumbre cooperativa sedimentada por los siglos, le merecen a Miroshevski la más absoluta desconfianza y escepticismo, sentimientos que se traducen en la calificación del pensamiento de Mariátegui como "populista"

La "teoría” de Mariátegui, según la cual la comunidad indígena peruana no sufrió ningún cambio en el último siglo y conservó totalmente su estructura patriarcal, está construida en el aire. El capitalismo sentó allí sus raíces, entrelazándose estrechamente con las formas de economía precapitalista (semifeudales y semiesclavistas) provocando serios cambios en la organización interna de la comunidad indígena. Cerrar los ojos ante esto significa abandonar la fuerte postura de los hechos para volar por las nieblas de la fantasía "populista"13.

Las conclusiones de Miroshevski no se apartan un ápice de las premisas, tal vez porque nunca fue otra la intención del artículo que la de esterilizar el potencial político de la estrategia trazada por un intelectual que no fue un provinciano utopista, sino un hombre que vivió de primera mano las experiencias del PCI en el momento de su nacimiento, que asistió al Congreso de Livorno (1921) y se vinculó estrechamente con los jóvenes de L'Ordine Nuovo, que interiorizó la experiencia del movimiento socialista en Europa, tal y como lo refleja su labor como articulista y su obra Defensa del marxismo, pero que, además, intentó hacer del marxismo una herramienta que se ajustara a las realidades de su propia nación. Todas estas consideraciones son poco relevantes para la mirada, finalmente piadosa y paternalista, de un Miroshevski que termina por concluir:

Las ideas de Mariátegui, en su aspecto primario, en el aspecto en que las desarrolló en el período precedente a su paso hacia la IC, fueron las ideas del "socialismo" pequeñoburgués, una versión especial de populismo adaptada al Perú. Mariátegui sinceramente quería luchar por el socialismo y estaba convencido de la revolución socialista en el Perú. No pertenecía a los demagogos burgueses (que, entre paréntesis, abundan en América Latina) para los cuales la

10 Cf. J. Murra, "El control vertical de un máximo de pisos ecológicos en la economía de las sociedades andinas", en J. Murra, El mundo andino. Población, medio ambiente y economía, Lima, Instituto de Estudios Peruanos y Pontificia Universidad Católica del Perú, 2004.

$11 \quad$ Ibidem, p. 64.

12 En otro lugar se referirá a la "fetichización populista" de la comunidad campesina, ibidem, p. 67.

13 Ibidem, p. 65, 
charlatanería sobre el socialismo es un medio de engañar a las masas trabajadoras. Pero sus puntos de vista nada tienen en común con el socialismo proletario. Sus ideas fueron los sueños utópicos de un intelectual pequeñoburgués en un país campesino, atrasado ${ }^{14}$.

Realizar una valoración crítica de la interpretación de Miroshevski sobre el pensamiento de Mariátegui requiere que presentemos el debate en su contexto histórico. Nos encontramos en los años en los que en la URSS se adentraba en un proceso de empobrecimiento del debate y creciente simplificación de las categorías del materialismo histórico. Por voluntad de Stalin, quien - como revela la anécdota de David Ryazanov- no tenía a la indagación teórica como uno de sus puntos fuertes ${ }^{15}$, las figuras fundamentales del socialismo revolucionario del siglo XIX, tales como Herzen o Chernyshevski, fueron silenciadas por decreto y su pensamiento estigmatizado bajo el rótulo de "populistas" - categoría sólo comparable en ese momento con la de "trotskista"16-, hasta el punto de que, como sostiene Franco Venturi, llegados a 1950:

(...) en el mejor de los casos, la apasionada discusión [sobre el legado de los populistas] se había convertido en severa erudición; la herencia se había reducido a unas frases de Lenin, eternamente repetidas, y había caído el más completo silencio sobre los revolucionarios -como los hombres de la Narodnaya volia- que intentaron con más intensidad que los otros unir estrechamente ideas y acción ${ }^{17}$.

Mariátegui fue, por tanto, el significante a través del cual Miroshevski combatió en una batalla oblicua cuyo verdadero escenario se estaba librando al interior de la URSS. Sin embargo, la línea trazada por su crítica abrió un surco por el que transitó una parte significativa del marxismo latinoamericano del siglo XX. Analizar los elementos constitutivos de la propuesta original de Mariátegui, más allá de las batallas internas en el seno de la Internacional Comunista, se antoja una tarea fundamental para nuestra intelectualidad, pero aún más para aquellos hombres y mujeres encargados de diseñar estrategias políticas en un espacio andino que ha visto cómo, década tras década, la promesa del advenimiento del proletariado industrial como clase revolucionaria seguía sin llegar.

\section{La comunidad: origen y destino}

Las reflexiones de José Carlos Mariátegui sobre el problema del indio en el Perú -y en el mundo andino en ge-

15 Jonathan Sanders refiere el episodio en el que David Ryazanov, director del Instituto Marx-Engels-Lenin, interrumpió un discurso pronunciado por Stalin al grito de: "Basta, Koba, no hagas el tonto, todo el mundo sabe que la teoría no es tu fuerte". J. Sanders, "La escena rusa: nota biográfica”, en T. Shanin, El Marx tardio y la vía rusa. Marx y la periferia del capitalismo, Madrid, Editorial Revolución, 1990 , p. 225

16 J. Aricó, op. cit., p. 35.

17 F. Venturi, El populismo ruso (Tomo I), Madrid, Revista de Occidente, 1975 , p. 10 .
}

neral- lo condujeron una y otra vez a identificarlo con el otro gran problema legado por la Colonia: el problema de la tierra. No es casual, por tanto, que los dos primeros ensayos que componen la obra capital de Mariátegui, los Siete ensayos de interpretación de la realidad peruana, lleven por título "El problema del indio" y "El problema de la tierra". Una y otra problemática se hallan entrelazadas de tal manera en la historia económica y social peruana que - parafraseando a Spinoza- podríamos pensar en ellas como natura naturans/natura naturata de una misma tragedia. Sin embargo, Mariátegui detecta un tercer elemento capaz de articular ambas cuestiones y abrir una vía de escape que supere las falsas soluciones provenientes del maltrecho feudalismo gamonal o de las cándidas pedagogías liberales, la comunidad indígena:

Congruentemente con mi posición ideológica, yo pienso que la hora de ensayar en el Perú el método liberal, la fórmula individualista, ha pasado ya. Dejando aparte las razones doctrinales, considero fundamentalmente este factor incontestable y concreto que da un carácter peculiar a nuestro problema agrario: la supervivencia de la comunidad y de elementos de socialismo práctico en la agricultura y la vida indígenas ${ }^{18}$.

El ayllu, que supo ser en su día la célula sobre la que se levantó el colosal Tawantinsuyu y que sobrevivió a los múltiples intentos de disolución a lo largo de la Colonia hispánica y de la república independiente, se transformaba en la propuesta mariateguiana en la célula sobre la que levantar la nueva sociedad socialista. No son pocos los artículos polémicos, o los fragmentos ensayísticos donde el fundador de la revista Amauta defendió la pervivencia de la comunidad como factor sobre el cual apoyarse a la hora de refundar sobre bases marxistas la nación peruana, pero tal vez en ninguno de ellos se defiende de forma tan clara y contundente la solución para este drama jánico de la tierra y del indio, como en el documento enviado por Mariátegui al Congreso Constituyente de la Confederación Sindical Latinoamericana, celebrado en Montevideo en mayo de 1929. Dicho documento ha llegado hasta nosotros bajo el título de $E l$ problema de las razas en América Latina y en él puede leerse lo siguiente:

Las "comunidades" que han demostrado bajo la opresión más dura condiciones de resistencia y persistencia realmente asombrosas, representan en el Perú un factor natural de socialización de la tierra. El indio tiene arraigados hábitos de cooperación. Aun cuando de la propiedad comunitaria se pasa a la apropiación individual y no sólo en la sierra sino también en la costa, donde un mayor mestizaje actúa contra las costumbres indígenas, la cooperación se mantiene; las labores pesadas se hacen en común. La "comunidad" puede transformarse en cooperativa, con mínimo esfuerzo. La adjudicación a las "comunidades" de las tierras de los latifundios, es en la sierra la solución que reclama el problema agrario ${ }^{19}$.

18 J. C. Mariátegui, Siete ensayos de interpretación de la realidad peruana, Caracas, Fundación Biblioteca Ayacucho, 2007, p. 41.

19 J. C. Mariátegui, "El problema de las razas en América Latina", en J.C. Mariátegui, Política revolucionaria: Contribución a la crítica 
Es necesario comprender que, más allá de la crítica imprecisa de Miroshevski y de todos aquellos que lo siguieron en este punto, Mariátegui escribió los Siete ensayos... y todos sus artículos de análisis histórico con un afán genealógico tendiente a desnaturalizar las estratificaciones políticas, económicas y sociales de un presente cuyas raíces se hunden en el proceso colonial y prosiguen -incluso se agudizan- tras las independencias nacionales. El presente para el cual se procura trazar una estrategia de renovación socialista, no puede ser comprendido correctamente sin una reconstrucción histórica profunda. El apotegma leninista -aquel que reza que "sin teoría revolucionaria, no puede haber tampoco movimiento revolucionario" 20 incorporaba en el caso de Mariátegui otra consigna igual de impostergable: sin reinterpretación histórica no puede haber teoría revolucionaria ni revolución alguna. La urgencia que estas tareas imponían, trazan el dramático cuadro de los revolucionarios latinoamericanos en la primera mitad del siglo XX.

Es a partir de este marco que debe ser interpretada la revalorización de Mariátegui de la comunidad indígena. El proletariado del Perú en la década del 20' era escaso, joven y desorganizado. Como refieren Semionov y Shulgovski, en 1927 el Perú contaba con sólo 50.000 obreros industriales ${ }^{21}$ que, si bien ya se habían iniciado en las luchas por el mejoramiento de las condiciones laborales y habían organizado algunas huelgas relevantes, su conciencia de clase aún no había trascendido la dimensión gremial y corporativa. Por otra parte, los 28.000 trabajadores que conformaban el sector minero se hallaban en su mayoría en un estado "transicional" que los situaba entre la producción agrícola, que no habían abandonado por completo, y la retribución salarial, que no colmaba siquiera la mayor parte de su reproducción como trabajador ${ }^{22}$. En este escenario, la apuesta de

socialista (Tomo 4, Defensa del marxismo y otros escritos), Caracas, Fundación editorial El perro y la rana, 2010, p. 79.

20 V. Lenin, “¿Qué hacer? Problemas candentes de nuestro movimiento", en V. Lenin, Obras Completas (Tomo V), Madrid, Akal, 1976, p. 376.

21 S. Semionov y A. Shulgovski, "El papel de Mariátegui en la formación del Partido Comunista del Perú”, en J. Aricó (ed.), Mariátegui y los orígenes del marxismo latinoamericano, México, Pasado y Presente, 1980, p. 167.

22 El excepcional trabajo de Heraclio Bonilla, El minero de los Andes, describe a la perfección este carácter "transicional" del minero, a medio camino entre el campesino y el proletario, entre lo feudal y lo capitalista, hecho que denota su carácter de trabajador híbrido. Esta hibridación o mestizaje económico no necesariamente debe ser interpretado como un hándicap, sino que es pensada por el propio Bonilla -y por Mariátegui en su tiempo- como una vía de conmensurabilidad y diálogo entre los condenados de la tierra y los de las minas, entre los que sudan sobre las obstinadas haciendas, y los que se desvanecen lentamente en las monótonas fábricas. Bonilla, al referir sus motivaciones a la hora de investigar la formación del proletariado minero en el Perú de comienzos del siglo XX, señala: "Este interés nace también de la percepción de la naturaleza tan peculiar de este proletariado minero: su estructural transicionalidad. Con esta expresión oscura deseo señalar la peculiar situación de este proletario quien, pese a conservar tercamente sus lazos con el mundo campesino, no es más un campesino, pero no es tampoco un «proletario» à part entière. Esta posición señala sus límites como clase, pero también sus considerables potencialidades de movilización y de articulación con otras fuerzas sociales" (H. Bonilla, El minero de los Andes, Lima, Instituto de Estudios Peruanos, 1974, p. 16).
Mariátegui por la comunidad es la apuesta por lo que hay de cooperativo en el panorama nacional peruano; con la sola comunidad indígena no basta, pero constituiría un sinsentido destruirla para tener que reconstituirla en un futuro socialismo. Y es precisamente esta posición la que defiende Mariátegui cuando redacta los Principios programáticos del Partido Socialista [1928]:

El socialismo encuentra lo mismo en la subsistencia de las comunidades que en las grandes empresas agrícolas, los elementos de una solución socialista de la cuestión agraria, solución que tolerará en parte la explotación de la tierra por los pequeños agricultores ahí donde el yanaconazgo o la pequeña propiedad recomiendan dejar a la gestión individual, en tanto que se avanza en la gestión colectiva de la agricultura, las zonas donde ese género de explotación prevalece $^{23}$.

Probablemente, lo que muchos de los detractores de Mariátegui olvidaron -o hicieron por olvidar- es que en ningún caso el Amauta propugna una restauración del Tawantinsuyu. Lejos se halla, uno de los marxistas latinoamericanos más brillantes de su tiempo, de dejarse arrastrar a través de "las nieblas de la fantasía" - como lo acusaba sarcásticamente Miroshevski-; Mariátegui no fue un utopista, sino un constructor político que levantó su teoría sobre un suelo andino donde brotan semillas revolucionarias muy diferentes a las que encontramos en la Europa Occidental de comienzos del siglo XX. Semillas que están estrechamente vinculadas con el ayllu, cuyo origen es muy anterior a la tardía consolidación del Estado incaico. El siguiente pasaje disipa -a nuestro entender-todo posible malentendido acerca del verdadero planteamiento del Amauta en relación con el legado incaico y su potencial futuro ${ }^{24}$ :

J.C. Mariátegui, Principios programáticos del Partido Socialista, en J.C. Mariátegui, Política revolucionaria: Contribución a la crítica socialista (Tomo 5, Ideología y política y otros escritos), Caracas, Fundación editorial El perro y la rana, 2010, pp. 188-189.

24 En otro pasaje, en el que Mariátegui se opone fervorosamente a las tesis defendidas por Augusto Aguirre Morales en su libro El pueblo del Sol, puede corroborarse el modo pertinaz en el que el pensador moqueguano sostiene su planteamiento en relación con el legado incaico: "Si la evidencia histórica del comunismo inkaiko no apareciese incontestable, la comunidad, órgano específico de comunismo, bastaría para despejar cualquier duda. El «despotismo» de los Inkas ha herido, sin embargo, los escrúpulos liberales de algunos espíritus de nuestro tiempo. [...] El comunismo moderno es una cosa distinta del comunismo inkaico. Esto es lo primero que necesita aprender y entender el hombre de estudio que explora el Tawantinsuyo. Uno y otro comunismo son un producto de diferentes experiencias humanas. Pertenecen a distintas épocas históricas. Constituyen la elaboración de disímiles civilizaciones. La de los inkas fue una civilización agraria. La de Marx y Sorel es una civilización industrial. En aquélla el hombre se sometía a la naturaleza. En ésta la naturaleza se somete a veces al hombre. Es absurdo, por ende, confrontar las formas y las instituciones de uno y otro comunismo. Lo único que puede confrontarse es su incorpórea semejanza esencial, dentro de la diferencia esencial y material de tiempo y de espacio. Y para esta confrontación hace falta un poco de relativismo histórico. [...] Hoy un orden nuevo no puede renunciar a ninguno de los progresos morales de la sociedad moderna. El socialismo contemporáneo -otras épocas han tenido otros tipos de socialismo que la historia designa con diversos nombres-es la antitesis del liberalismo; pero nace de su entraña y se nutre de su experiencia [el destacado es nuestro]. No desdeña ninguna de sus conquistas intelectuales. No escarnece y vilipendia sino sus limitaciones. Aprecia y comprende todo lo que en la idea liberal hay de positivo: condena y ataca sólo lo que en esta idea hay de ne- 
Pero esto, lo mismo que el estímulo que se preste al libre resurgimiento del pueblo indígena, a la manifestación creadora de sus fuerzas y espíritus nativos, no significa en lo absoluto una romántica y antihistórica tendencia de reconstrucción o resurrección del socialismo incaico, que correspondió a condiciones históricas completamente superadas, y del cual sólo quedan, como factor aprovechable dentro de una técnica de producción perfectamente científica, los hábitos de cooperación y socialismo de los campesinos indígenas. El socialismo presupone la técnica, la ciencia, la etapa capitalistas, y no puede importar el menor retroceso en la adquisición de las conquistas de la civilización moderna, sino por el contrario la máxima y metódica aceleración de la incorporación de estas conquistas en la vida nacional ${ }^{25}$.

En este punto radica la novedad del planteamiento mariateguiano, la clave que le permite trascender las ensoñaciones románticas y, al mismo tiempo, esquivar los esquematismos reduccionistas. La vía abierta por Mariátegui -y que continúan en buena medida los pensadores marxistas más relevantes del espacio andino como René Zavaleta Mercado y Álvaro García Linera- es la de encauzar las dos razones revolucionarias realmente existentes: indigenismo y marxismo. Sin el indigenismo, el marxismo es un esquema vaciado que espera -ahora sí, utópicamente - la consumación definitiva de la subsunción real del capital y el advenimiento de un proletariado industrial para organizar la revolución; sin el marxismo, el indigenismo es presa fácil de las panaceas pedagógicas y de la reproducción del esquema tributarista colonial. Es por esta razón que, en un artículo publicado en la revista Amauta, titulado La nueva cruzada pro Indígena [1927], Mariátegui defendería:

La levadura de las nuevas reivindicaciones indigenistas es la idea socialista, no como la hemos heredado instintivamente del extinto inkario sino como la hemos aprendido de la civilización occidental, en cuya ciencia y en cuya técnica sólo romanticismos utopistas pueden dejar de ver adquisiciones irrenunciables y magníficas del hombre moderno $^{26}$.

El lugar del indígena en la estrategia planteada por Mariátegui es, indudablemente, el punto donde se bifurcan los senderos trazados por el Komintern y por el Partido Socialista Peruano. El autor de La escena contemporánea rechaza por completo la senda consistente en transformar a los trabajadores agrícolas en proletarios rurales; entiende, por el contrario, que la costumbre cooperativa del indígena vinculado a las comunidades lo exoneran de la necesidad de un nuevo despojo - despojo que, por otra parte, se había ensayado infructuosamente a través de las reformas agrarias liberales- y lo colocan en condiciones de pasar directamente a una

gativo y temporal" (J.C. Mariátegui, Siete ensayos de interpretación de la realidad peruana, op. cit., nota pp. 63-65).

25 J.C. Mariátegui, Principios programáticos del Partido Socialista, op. cit., pp. 188-189.

26 J.C. Mariátegui, "La nueva cruzada pro Indígena", en J.C. Mariátegui, Politica revolucionaria: Contribución a la crítica socialista (Tomo 5, Ideología y política y otros escritos), Caracas, Fundación editorial El perro y la rana, 2010, pp. 194-195. sociedad socialista, incorporando aquellas adquisiciones positivas logradas por el sistema capitalista sin tener que someterse -en términos del propio Marx- a las "horcas caudinas" del capital ${ }^{27}$.

En definitiva, sólo un marxismo adaptado a las condiciones específicas en las que tienen lugar las luchas locales puede trascender lo eidético y transformarse en un arma para la revolución. El socialismo es un horizonte y, como tal, se ve recortado e interferido por los escarpados cerros que se agolpan en la lontananza de la majestuosa cordillera de los Andes. A diferentes alturas, entre los diversos pisos ecológicos que ordenaron la política y la economía del espacio entre los pueblos andinos precolombinos - quizás debiéramos decir pretoledanos-, se encuentran las masas trabajadoras que harán posible, o no, el socialismo. Por tanto, debe tenerse como premisa irrenunciable -tal y como defendió Mariátegui- que "en el Perú las masas, -la clase trabajadora-son, en sus cuatro quintas partes, indígenas. Nuestro socialismo no sería, pues, peruano, -ni sería siquiera socialismo- si no se solidarizase, primeramente, con las reivindicaciones indígenas" ${ }^{28}$. De lo que se trataba, en última instancia, era de interiorizar otra de las enseñanzas de Lenin, aquella que nos recuerda que "en el fondo, el «elemento espontáneo» no es sino la forma embrionaria de lo consciente" 29 y, por tanto, ningún revolucionario que se precie puede desentenderse de estas formas concretas en las que se expresa el sentir y las luchas de las masas.

El camino mariateguiano al socialismo incorpora en su seno el valor y las reivindicaciones indígenas, a través de la influencia directa de autores como Luis Valcárcel y su libro Tempestad en los Andes, o de Hildebrando Castro Pozo y su ensayo Nuestra Comunidad indígena, pero llevándolo a una nueva dimensión que sólo puede tener lugar en confluencia con los elementos adquiridos a través de la experiencia europea del propio Mariátegui. Estos elementos no son sino aquellos que provienen de las experiencias de luchas y debates en el seno del materialismo histórico. Es en ese punto, en el que los senderos dejan de bifurcarse para confluir, donde debe buscarse la solución de Mariátegui al problema del indio/problema de la tierra, una solución que pasa por la construcción de un marxismo indigenista o un indigenismo marxista, tal y como el propio Amauta concibiera:

Confieso haber llegado a la comprensión, al entendimiento del valor y el sentido de lo indígena, en nuestro tiempo, no por el camino de la erudición libresca, ni de la intuición estética, ni siquiera de la especulación teórica, sino por el camino, -a la vez intelectual, sentimental y práctico- del socialismo $^{30}$.

La comunidad -el ayllu-, al mismo tiempo sistema de producción y sistema de valores, es el órgano capaz

\footnotetext{
K. Marx, "Escritos sobre Rusia II. El porvenir de la comuna rural rusa", en K. Marx, Karl Marx. Escritos sobre la comunidad ancestral, La Paz, Vicepresidencia del Estado Plurinacional, p. 183.

28 J.C. Mariátegui, "Indigenismo y socialismo", en J.C. Mariátegui, Política revolucionaria: Contribución a la crítica socialista (Tomo 5, Ideología y política y otros escritos), Caracas, Fundación editorial El perro y la rana, 2010, p. 243

29 V. Lenin, op. cit., p. 382.

30 J.C. Mariátegui, Indigenismo y socialismo, op. cit., p. 244.
} 
de obtener del indígena "su máximo rendimiento como trabajador" ${ }^{\prime 31} \mathrm{y}$, a la vez, irradiar sus efectos materiales y morales a la construcción de un esquema social, político y económico de cooperativismo integra ${ }^{32}$. En la senda abierta por Mariátegui, la comunidad se presenta como el origen vivo y el destino -ya no agonizante, sino agonístico- del socialismo en el Perú.

\section{Marxismo más allá del obrerismo}

Intentar dar una respuesta al interrogante que titula este trabajo, esto es, si el pensamiento de José Carlos Mariátegui puede ser ubicado entre el marxismo y el populismo, requiere precisar, en primer lugar, qué interpretación damos del marxismo y, en particular, del marxismo en condiciones - por utilizar la categoría acuñada por Zavaleta Mercado- de abigarramiento; en segundo lugar, cuáles fueron las propuestas específicas de los populistas rusos del siglo XIX para la construcción del socialismo en un país atrasado y de base agraria; y, en tercer lugar, debemos dar cuenta de los puntos de encuentro entre algunas de las figuras más destacadas de este movimiento populista, en especial, Herzen y Chernyshevski, y el propio Karl Marx.

Si bajo la categoría "marxismo" entendiéramos el soporte teórico que da sostén a las prácticas revolucionarias de los obreros que se concentran en las grandes urbes industrializadas, entonces habríamos de reconocer que el marxismo no es una herramienta adecuada para pensar las estrategias emancipatorias de las naciones que emergieron de la colonización hispánica en América. Más allá de la indisimulada esperanza en el proceso de proletarización general de las condiciones laborales como palanca movilizadora de las luchas de las masas en torno a una causa común, esto es, la reversión del despojo y la apropiación privada de lo que antaño se presentaba como elemento común y compartido (medios de producción y herramientas de trabajo) ${ }^{33}$; debe decirse que el marxismo es mucho más que una teoría

31 J.C. Mariátegui, Siete ensayos de interpretación de la realidad peruana, op. cit., p. 67.

32 J.C. Mariátegui, "El porvenir de las cooperativas", en J.C. Mariátegui, Politica revolucionaria: Contribución a la crítica socialista (Tomo 5, Ideología y politica y otros escritos), Caracas, Fundación editorial El perro y la rana, 2010, pp. 223-224.

33 La esperanza de Marx - tal vez excesiva- en la reversión del proceso de la "llamada acumulación originaria" a través de una reapropiación social de lo que era común, queda explicitada en el siguiente pasaje del Tomo I de El Capital: "El modo capitalista de producción y de apropiación, y por tanto la propiedad privada capitalista, es la primera negación de la propiedad privada individual, fundada en el trabajo propio. La negación de la producción capitalista se produce por sí misma, con la necesidad de un proceso natural. Es la negación de la negación. Ésta restaura la propiedad individual, pero sobre el fundamento de la conquista alcanzada por la era capitalista: la cooperación de trabajadores libres y su propiedad colectiva sobre la tierra y sobre los medios de producción producidos por el trabajo mismo. La transformación de la propiedad privada fragmentaria, fundada sobre el trabajo personal de los individuos, en propiedad privada capitalista es, naturalmente, un proceso incomparablemente más prolongado, más duro y dificultoso, que la transformación de la propiedad capitalista, de hecho fundada ya sobre el manejo social de la producción, en propiedad social. En aquel caso se trataba de la expropiación de la masa del pueblo por unos pocos usurpadores; aquí se trata de la expropiación de unos pocos usurpadores por la revolucionaria obrerista. Las cartas y artículos de Marx sobre la India, los textos sobre la causa irlandesa y, en particular, lo que Teodor Shanin ha denominado "la vía rusa" ${ }^{34}$, nos invitan a descubrir un marxismo capaz de cuestionarse acerca de los caminos de lucha abiertos en aquellas regiones del planeta en las que el modo de producción capitalista aún no se ha convertido en la forma explotativa predominante.

Centrándonos en los comentarios realizados por el propio Marx en torno a algunos de los dilemas más acuciantes planteados por el movimiento revolucionario ruso de fines de la década de 1870, en especial aquellos que se desprenden de su carta a la redacción de Otiéchestviennie Zapiski (Anales de la Patria) [1878] y de los cuatro borradores de respuesta a la carta de la revolucionaria Vera Zasúlich [1881], podemos hacernos con una idea bastante precisa de la posición del pensador de Tréveris acerca de las vías convenientes para la elaboración de una estrategia revolucionaria en Rusia, y en general, para todos aquellos países atrasados que se encontrasen en una situación similar.

La pregunta planteada por la carta de Vera Zasúlich, revolucionaria rusa vinculada a la organización populista Chernyi Peredel [Reparto Negro], es la siguiente: ¿qué debemos hacer los revolucionarios rusos con la extendida comuna rural $[o b s h i n a]$ ?; y se cuestiona:

Una de dos: o bien esta comuna rural, libre de las exigencias desmesuradas del fisco, de los pagos a los señores de la administración arbitraria, es capaz de desarrollarse en la vía socialista, o sea de organizar poco a poco su producción y su distribución de los productos sobre las bases colectivistas, en cuyo caso el socialismo revolucionario debe sacrificar todas sus fuerzas a la manumisión de la comuna y a su desarrollo. O si, por el contrario, la comuna está destinada a perecer, no queda al socialista, como tal, sino ponerse a hacer cálculos, más o menos mal fundados, para averiguar dentro de cuántos decenios pasará la tierra del campesino ruso de las manos de éste a las de la burguesía y dentro de cuántos siglos, quizá, tendrá el capitalismo en Rusia un desarrollo semejante al de Europa occidental ${ }^{35}$.

masa del pueblo" (K. Marx, El Capital [Tomo I], México D.F., Siglo Veintiuno, 2008, pp. 953-954).

34 Teodor Shanin recordaba en su introducción a Late Marx and the russian road, la importancia que tenía el ejemplo ruso en el pensamiento de Marx, hasta el punto de que -según Shanin-Marx pensaba que debía utilizar la situación de Rusia para elaborar el Tomo III de El Capital, de modo análogo a como había utilizado la historia particular de Inglaterra en el Tomo I: "Puede comprenderse toda la importancia del deseo declarado de Marx de utilizar a Rusia para el Volumen III de El Capital, tal y como había utilizado a Inglaterra en el Volumen I. Existen concepciones claramente diferentes del marxismo, una de las cuales se ve a sí misma como una deducción consistente a partir de El Capital, Volumen 1, utilizando toda la evidencia empírica que tiene a mano para defender su carácter absoluto y su universalidad. El texto que sigue ayudará a transformar el comentario de Marx sobre sí mismo en 1870 -"yo no soy un marxista"- de una simple anécdota, en una revelación fundamental del propio marxismo de Marx frente al de la primera generación de intérpretes" (T. Shanin, "Introducción", en El Marx tardio y la vía rusa. Marx y la periferia del capitalismo, Madrid, Editorial Revolución, 1990, p. 9).

35 V. Zasúlich, Carta de Vera Zasúlich a Marx [16 de febrero de 1881], en Marx, K., Escritos sobre la comunidad ancestral, La Paz, Bolivia, Vicepresidencia del Estado Plurinacional, 2015, pp. 175-176. 
La disyuntiva planteada por Zasúlich encierra -a nuestro entender- el núcleo en torno al cual orbita el drama estratégico de las formaciones sociales abigarradas y, por tanto, supone uno de los mayores desafíos para una teoría-herramienta como la del materialismo histórico, a saber: si se ha de esperar que los debilitados tejidos comunitarios, aquellos que aún conservan un habitus cooperativo y una apropiación comunal del excedente, acaben por fenecer como consecuencia del torbellino capitalista, para recién allí, como la flor que emerge del lodo, confiar en que la nueva clase proletaria aunará sus fuerzas para enfrentar a la burguesía; o bien, si en aquellos lugares donde la comunidad aún funciona como célula viva de producción y como espacio abierto de participación política, puede el socialismo apoyarse en ella como suelo sobre el que cimentar su proyecto. Pero, además, la pregunta de Zasúlich interpela indirectamente a Marx sobre la recta interpretación del ejemplo inglés que sirve como base histórica al Tomo I de $E l$ Capital: ¿es acaso inexorable que la comuna rural rusa acabe disolviéndose, dando lugar a la apropiación privada de sus tierras e instrumentos de trabajo?, o dicho en otros términos, ¿existe una teleología en la historia que conduce a los distintos pueblos a atravesar las peripecias que dieron como resultado el capitalismo británico? Interpretación histórica y planteamiento estratégico se presentan, pues, como las dos caras de una misma moneda. Marx fue perfectamente consciente de la importancia del dilema que se le planteaba y respondió:

Remontándonos mucho, por todas partes hallamos en Europa occidental la propiedad común de un tipo más o menos arcaico; de todas partes ha desaparecido con el progreso social. ¿Por qué no habría de ocurrir lo mismo, exclusivamente, en Rusia?

Respondo: porque en Rusia, gracias a una excepcional combinación de circunstancias, la comuna rural, establecida todavía en escala nacional, puede irse desprendiendo de sus caracteres primitivos y desarrollando directamente como elemento de la producción colectiva en escala nacional. Es precisamente gracias a la contemporaneidad de la producción capitalista como puede apropiarse todas sus adquisiciones positivas y sin pasar por sus peripecias «terribles〉 espantosas. Rusia no vive aislada del mundo moderno; y tampoco es presa de un conquistador extranjero como en las Indias orientales ${ }^{36}$.

El elemento fundamental en la respuesta marxiana debe buscarse por el lado de la "contemporaneidad" de la estructura social comunitaria y el nivel alcanzado por el desarrollo de las fuerzas productivas capitalistas. A partir de esta tensa coexistencia puede pensarse la viabilidad histórica de una "apropiación por parte del pueblo" - como Marx señalaba para el caso indio en $1853^{37}$ - de los avances legados por el capitalismo,

36 K. Marx, Escritos sobre la comunidad ancestral, op. cit., pp. 177178.

37 En un artículo del 22 de julio de 1853, que lleva por título Futuros resultados de la dominación británica en la India, Marx señalaba lo siguiente: "Todo cuanto se vea obligada a hacer en la India la burguesía inglesa no emancipará a las masas populares ni mejorará sustancialmente su condición social, pues tanto lo uno como lo otro sin tener que atravesar, como el poeta florentino, por su infierno y purgatorio. No se trata, pues, de la conservación del arado manual y la tracción a sangre, sino de la complementación orgánica de los avances técnicos -en sentido amplio-derivados del desarrollo capitalista y las relaciones de producción comunales establecidas a escala nacional. Por lo tanto, si bien -como recuerda Lenin en El Estado y la revolución-, "el comunismo procede del capitalismo, se desarrolla históricamente del capitalismo, es el resultado de la acción de una fuerza social engendrada por el capitalismo ${ }^{38}$ ", esto no implica que el movimiento de masas deba aguardar pacientemente a que el modo de producción capitalista disuelva todos los elementos precapitalistas para construir sobre sus ruinas la revolución; pero sí implica que la única posibilidad de que la obshina sobreviva como semilla socialista es que se sirva de los elementos progresivos del capitalismo y los incorpore en sus dinámicas... pero para ello todavía hace falta un elemento fundamental:

Para salvar a la comuna rusa hace falta una revolución rusa [el destacado es nuestro] [...] Si la revolución se efectúa en el momento oportuno, si concentra todas sus fuerzas [...] en asegurar el libre desenvolvimiento de la comuna rural, ésta se revelará pronto un elemento regenerador de la sociedad rusa y un elemento de superioridad sobre los países subyugados por el régimen capitalista ${ }^{39}$.

Si esta es, a grandes rasgos, la vía que el propio Marx entendió como la más adecuada para el desarrollo del movimiento revolucionario en la Rusia de la segunda mitad del siglo XIX, sin contar la gran estima que sintió por algunos de los principales representantes del grupo Narodnaya volia [La Voluntad del Pueblo], debemos indagar cuál fue la posición de los dos principales ideólogos del movimiento naródniki ruso, Herzen y Chernyshevski, para ver hasta qué punto se bifurcan los caminos del marxismo y del populismo. A pesar del silencio y el escarnio en el que cierta vulgata marxista pretendió confinar los ricos desarrollos teóricos y políticos del movimiento populista ruso, la semilla sembrada por aquellos hombres ha vuelto a brotar con fuerza en los debates intelectuales posteriores a la muerte de Stalin. Repensar los vínculos entre marxismo y populismo nos obliga, pues, tanto a redefinir al primero más allá del obrerismo, como a recuperar en su contexto histórico las disyuntivas estratégicas que hubieron de enfrentar los segundos, procurando escapar a los reduccionismos que separaron a ambas razones revolucionarias.

Dado que esta tarea implica una labor colectiva y epocal y, por tanto, que trasciende ampliamente los modestos horizontes de este trabajo, bastará con presentar aquí algunas pinceladas que den cuenta del principal di-

no sólo dependen del desarrollo de las fuerzas productivas, sino de su apropiación por el pueblo [el destacado es nuestro]. Pero lo que sí no dejará de hacer la burguesía es sentar las premisas materiales necesarias para la realización de ambas empresas" (K. Marx, "Futuros resultados de la dominación británica en la India”, en K. Marx, Sobre el modo de producción asiático, Barcelona, Martínez Roca, 1972, p. 105).

38 V. Lenin, El Estado y la revolución, Madrid, Fundación Federico Engels, 1997, p. 106.

39 K. Marx, Escritos sobre la comunidad ancestral, op. cit., p. 189. 
lema planteado a los populistas rusos: ¿qué hacer con la comuna rural rusa y cómo conjugarla con los avances capitalistas provenientes de la Europa occidental? La respuesta de Herzen -“creador del populismo", en palabras de Franco Venturi ${ }^{40}$ - es la siguiente:

El poderoso pensamiento occidental, último término de su largo desarrollo histórico, será el único que pueda fecundar los gérmenes que dormitan en el seno del orden patriarcal de los pueblos eslavos. El artel (la asociación obrera) y la comuna rural, la distribución de los productos y los campos, la asamblea comunal y la reunión de las aldeas en distritos que se autoadministran, todo eso servirá de bases para nuestro futuro régimen de libertad nacional. Pero esas bases aún no son sino piedras dispersas y el edificio de nuestro futuro jamás tendrá más que cimientos sin el pensamiento occidental ${ }^{41}$.

¡Qué lejos se halla Herzen de los romanticismos eslavófilos a los que se ha querido reducir al movimiento populista! Herzen, hombre que vivenció con pasión la experiencia de la insurrección popular de París de 1848, no podía de ninguna forma desestimar el legado de Occidente en la construcción de un socialismo a la altura de las demandas nacionales rusas. La obshina, el artel $\mathrm{y}$ todos los elementos cooperativos propiamente rusos en combinación con las experiencias europeas de lucha -teórica y práctica- e, inclusive, con algunos de los elementos que el enemigo ha desarrollado, bajo la condición de una redefinición en un sentido socialista: esta es la vía del populismo de Herzen. Y la vía abierta por Herzen será continuada por Chernyshevski, quien supo ver que los desarrollos de las naciones más avanzadas, lejos de suponer el camino inexorable a recorrer por las más atrasadas, abrían la posibilidad de que estas pudieran exonerar las penurias padecidas por aquellas:

Cuando ciertos fenómenos sociales en determinada nación alcanzan un estado avanzado de desarrollo, la evolución de los fenómenos hasta ese mismo estado en otras naciones atrasadas puede alcanzarse mucho más rápidamente que en la nación adelantada... Esta aceleración consiste en el hecho de que el desarrollo de ciertos fenómenos sociales en las naciones atrasadas, gracias a las influencias de la nación adelantada, se ahorra una etapa intermedia y salta directamente de una etapa inferior a otra más elevada ${ }^{42}$.

Son evidentes, pues, las conexiones entre los planteamientos de los grandes artífices intelectuales del movimiento naródniki y las bosquejadas por Marx en sus cuatro tentativas de respuesta a la carta de Vera Zasúlich. En última instancia, todos ellos coinciden en la negación de una teleología y es en este punto donde se conjugan los dos horizontes de lucha: por un lado, en el análisis crítico del potencial socialista de algunas estructuras

F. Venturi, op. cit., p. 99.

41 A. Herzen, Problemy izuchenia Gertsena [Problemas del estudio de Herzenj, Akademiya nauk SSSR, M. 1963, p. 9], citado en F. Venturi, op. cit., p. 47.

42 N. Chernyshevski, Polnoe Sobranie Schinenii, vol. 5, pp. 288-289, citado en H. Wada, "Marx y la Rusia revolucionaria", en T. Shanin, El Marx tardio y la vía rusa. Marx y la periferia del capitalismo, Madrid, Editorial Revolución, 1990, p. 69. precapitalistas y, por el otro, en la comprensión de que toda teoría revolucionaria es, por definición, contraria a los apresamientos reduccionistas de cualquier filosofía de la historia, tal y como dejara entrever Marx en su carta a la redacción de Otiéchestviennie Zapiski:

Si Rusia aspira a convertirse en un país capitalista calcado sobre el patrón de los países de la Europa occidental -y durante los últimos años, hay que reconocer que se ha infligido no pocos daños en este sentido-, no lo logrará sin antes convertir en proletarios a una gran parte de sus campesinos; y una vez que entre en el seno del régimen capitalista, tendrá que someterse a las leyes inexorables, como otro pueblo cualquiera. Esto es todo. A mi crítico [se refiere a Mijailovski] le parece, sin embargo, poco. A todo trance quiere convertir mi esbozo histórico sobre los orígenes del capitalismo en la Europa occidental en una teoría filosófico-histórica sobre la trayectoria general a que se hallan sometidos fatalmente todos los pueblos, cualesquiera que sean las circunstancias históricas que en ellos concurran, para plasmarse por fin en aquella formación económica que, a la par que el mayor impulso de las fuerzas productivas, del trabajo social, asegura el desarrollo del hombre en todos y cada uno de sus aspectos. (Esto es hacerme demasiado honor $\mathrm{y}$, al mismo tiempo, demasiado escarnio $)^{43}$.

Marxismo y populismo, pues, dos líneas que, a pesar de su histórico divorcio, tienden a encontrarse allí donde la destrucción creadora capitalista no ha podido arrancar de raíz el legado y la potencia revolucionaria de la vida comunitaria.

\section{Consideraciones finales. Mariátegui: marxista- populista}

Miroshevski tenía razón: Mariátegui fue un populista, aun sin saberlo. Marx también lo fue, o al menos no lo fue menos que Chernyshevski cuando imaginó los caminos revolucionarios para la atrasada Rusia del siglo XIX. Las soluciones defendidas por Mariátegui para el bifronte problema del indio y la tierra, fueron análogas a las defendidas por los naródniki, de los cuales, por otra parte, el Amauta no pudo tener conocimiento más allá de los textos polémicos de Lenin. El potencial socialista que el pensador peruano veía en el ayllu andino es idéntico al que reconocían Herzen, Chernyshevski, Zasúlich y Marx en la obshina rusa y no titubeó a la hora de colocar en primer lugar la cuestión indígena como tarea a resolver por un socialismo que se pretendiera peruano.

Ahora bien, la pregunta que prosigue su curso, aun en nuestros días en los que el "populismo" lejos está de poder ser identificado con el movimiento naródniki, es la siguiente: ¿qué hacemos con el término "populista"? Y aquí no podemos más que coincidir con Marco D'Eramo cuando afirma que "si nadie se autoproclama populista, entonces el término dice mucho más del que lo profiere que de quien es simplemente denigrado por

43 K. Marx, "Carta a la redacción de Otiéchestviennie Zapiski", en K. Marx, Escritos sobre la comunidad ancestral, op. cit., p. 207. 
él" y, por lo tanto, "la noción de populismo es un instrumento hermenéutico útil sobre todo para identificar y caracterizar a aquellas facciones políticas que tachan a sus adversarios de populismo" ${ }^{4}$. Los enemigos del "populismo" son siempre las nuevas oligarquías y lo cierto es que en la URSS también existieron oligarquías que irradiaron sus efectos a algunos "revolucionarios" latinoamericanos que no se atrevían a alcanzar la mayoría de edad. Una de las consecuencias intelectuales más nocivas de esta oligarquización es la naturalización de la historia y la concomitante estandarización de la estrategia revolucionaria que, como consecuencia, promueve la acusación de herejía a cualquier tentativa estratégica que se aparte de los lineamientos oficiales.

Pero Mariátegui no fue un teólogo de la historia, ni un párroco provinciano de la revolución, fue un verdadero marxista-populista, un agonista convicto y confeso, que supo legar a los intelectuales latinoamericanos y a las masas trabajadoras que en el siglo XXI continúan luchando contra las mismas iniquidades, la imborrable enseñanza de que "no vale la idea perfecta, absoluta, abstracta, indiferente a los hechos, a la realidad cambiante y móvil; vale la idea germinal, concreta, dialéctica, operante, rica en potencia y capaz de movimiento"45.

\section{Bibliografía}

Althusser, L., "Carta a Dal Sasso", en Para leer El Capital, México D.F., Siglo XXI, 2004.

Aricó, J., "Introducción”, en Aricó, J. (ed.), Mariátegui y los orígenes del marxismo latinoamericano, México, Pasado y Presente, 1980.

Bonilla, H., El minero de los Andes, Lima, Instituto de Estudios Peruanos, 1974.

D’ Eramo, M., "El populismo y la nueva oligarquía", New left review, 82, pp. 7-40, 2013.

Lenin, V., “¿Qué hacer? Problemas candentes de nuestro movimiento”, en V. Lenin, Obras Completas (Tomo V), Madrid, Akal, 1976.

-, El Estado y la revolución, Madrid, Fundación Federico Engels, 1997.

Mariátegui, J.C., Siete ensayos de interpretación de la realidad peruana, Caracas, Fundación Biblioteca Ayacucho, 2007.

-, "El problema de las razas en América Latina", en Mariátegui, J.C., Política revolucionaria: Contribución a la crítica socialista (Tomo 4, Defensa del marxismo y otros escritos), Caracas, Fundación editorial El perro y la rana, 2010.

-, "Principios programáticos del Partido Socialista", en Mariátegui, J.C., Política revolucionaria: Contribución a la crítica socialista (Tomo 5, Ideología y política y otros escritos), Caracas, Fundación editorial El perro y la rana, 2010.

-, "La nueva cruzada pro Indígena", en Mariátegui, J.C., Política revolucionaria: Contribución a la crítica socialista (Tomo 5, Ideología y política y otros escritos), Caracas, Fundación editorial El perro y la rana, 2010.

-, "Indigenismo y socialismo", en Mariátegui, J.C., Política revolucionaria: Contribución a la crítica socialista (Tomo 5, Ideología y política y otros escritos), Caracas, Fundación editorial El perro y la rana, 2010.

-, "El porvenir de las cooperativas", en Mariátegui, J.C., Politica revolucionaria: Contribución a la crítica socialista (Tomo 5, Ideología y política y otros escritos), Caracas, Fundación editorial El perro y la rana, 2010.

Marx, K., "Escritos sobre Rusia II. El porvenir de la comuna rural rusa", en Marx, K., Karl Marx. Escritos sobre la comunidad ancestral, La Paz, Vicepresidencia del Estado Plurinacional, 2015.

-, El Capital [Tomo I], México D.F., Siglo XXI, 2008.

-, "Futuros resultados de la dominación británica en la India", en Marx, K. Sobre el modo de producción asiático, Barcelona, Martínez Roca, 1972.

-, "Carta a la redacción de Otiéchestviennie Zapiski”, en Marx, K., Karl Marx. Escritos sobre la comunidad ancestral, La Paz, Vicepresidencia del Estado Plurinacional, 2015.

Miroshevski, V.M., "El «populismo» en el Perú. Papel de Mariátegui en la historia del pensamiento social latinoamericano", en Aricó, J. (ed.), Mariátegui y los orígenes del marxismo latinoamericano, México, Pasado y Presente, 1980.

Murra, J., "El control vertical de un máximo de pisos ecológicos en la economía de las sociedades andinas", en J. Murra, El mundo andino. Población, medio ambiente y economía, Lima, Instituto de Estudios Peruanos y Pontificia Universidad Católica del Perú, 2004.

Núñez Valdivia, J., "José Carlos Mariátegui y el materialismo dialéctico”, en Aricó, J. (ed.), Mariátegui y los orígenes del marxismo latinoamericano, México, Pasado y Presente, 1980.

Sanders, J., "La escena rusa: nota biográfica", en Shanin, T., El Marx tardío y la vía rusa. Marx y la periferia del capitalismo, Madrid, Editorial Revolución, 1990.

Semionov, S. y Shulgovski, A., "El papel de Mariátegui en la formación del Partido Comunista del Perú", en Aricó, J. (ed.), Mariátegui y los orígenes del marxismo latinoamericano, México, Pasado y Presente, 1980.

Shanin, T., "Introducción", en Shanin, T., El Marx tardio y la vía rusa. Marx y la periferia del capitalismo, Madrid, Editorial Revolución, 1990.

Venturi, F., El populismo ruso (Tomo I), Madrid, Revista de Occidente, 1975.

Zasúlich, V., "Carta de Vera Zasúlich a Marx" [16 de febrero de 1881], en Marx, K., Escritos sobre la comunidad ancestral, La Paz, Bolivia, Vicepresidencia del Estado Plurinacional, 2015.

44 M. D’Eramo, "El populismo y la nueva oligarquía”, New left review, 82, pp. 7-40, 2013, pp. 11-12.
45 J. C. Mariátegui, "Editorial de Amauta, No 17, año II, Lima, septiembre de 1928”, en J.C. Mariátegui, Política revolucionaria: Contribución a la crítica socialista (Tomo 5, Ideología y política y otros escritos), Caracas, Fundación editorial El perro y la rana, 2010, p. 269. 